\title{
Best Practice Diffusion in a Polish National Investment Fund (NIF): a comparative study from an institutional theory perspective*
}

\author{
Charles Malone and R. David Kirk ${ }^{* *}$
}

This study is concerned with organisational re-design in former state owned enterprises in Poland as a consequence of the transition to a market economy. The study will examine the context of change in the former COMICON state; the rationale supporting organisational change activities; the triggers of change; organisation re-design; and the diffusion of business process improvement techniques in Polish manufacturing companies: lean production, total quality management, benchmarking as examples. A comparison of the experiences of senior managers in organisations undergoing change from within four sectors of manufacturing in Poland will be explored.

In dieser Arbeit wird die Neugestaltung der Organisation vormalig staatlicher Unternehmen in Polen unter die Lupe genommen, die als Konsequenz aus dem Übergang in eine Marktwirtschaft stattfindet. Das Konzept des Wandels in Polen soll untersucht werden, ebenso wie die Beweggründe für Veränderungen im Bereich Organisation, die Auslöser des Wandels, Neuformung der Organisation und die Diffusion von Verbesserungen in polnischen Unternehmen: Lean Production, Total Quality Management usw. Es wird ein Vergleich der Erfahrungen von hochrangigen Managern aus Unternehmen in vier Branchen, die sich im Wandlungsprozess befinden, durchgeführt.

\footnotetext{
${ }^{*}$ manuscript received: 25.06.1999, revised: 10.03.2000, accepted: 27.03.2000;

** Charles Malone is a Lecturer in Management at the University of Abertay Dundee in Scotland. In addition to his teaching, Charles is pursuing a $\mathrm{PhD}$ exploring the process of deinstutionalisation and re-institutionalisation. Charles presented a paper based on this work to the Irish Academy of Management Conference in Autumn 1998 and was co-winner of the IAM prize in the post-graduate stream. $R$. David Kirk, Division Leader, Organisation Management Division, Lecturer in Strategic Management, The University of Abertay Dundee.
} 


\section{The Contribution of Institutional Theory to Organisational Design and Management}

Formal organisations are generally understood to be structured systems of coordinated and controlled activities in which work is embedded in complex networks of technical relations. According to institutional theorists such as Meyer and Rowan (1977), formal organisational structures arise as reflections of dominant institutional rules guiding organisational relationships and processes. The source of such rationalisation is focused in the wider institutional context within which the organisation operates. In this respect, rather than viewing the firm as an organisation solely for the purposes of efficient co-ordination and control determined by one contractual producer-customer relationship, that they reflect a nexus of contracts or treaties with players operating internally and externally in relation to this complexity of interests and the influence of environmental factors.

Unlike its economic counterpart, institutional theory suggests that successful organisations, rather than reflecting only increased technical efficiency, adapt to become isomorphic with the environments in which they operate (Jones 1995). Isomorphism, in this sense, is the process in which organisational form will change or adapt to become consistent with the characteristics of its environment. By adopting a certain organisational form and internal structures, they legitimise their existence, thereby enhancing both their survival opportunities and their resources base (Rowlinson 1997).

Isomorphic adaptation can be achieved to a greater or lesser degree and such changes are a consequence of the interaction between organisations and internal and external institutional forces Tolbert and Zucker (1997). Jones (1995), listed three mechanisms for isomorphism of firms in institutional environments namely: coercive, mimetic and normative.

Coercive isomorphism refers to the process where organisational changes occur as a consequence of compulsion, either through: demands of state institutions and legislation; improved corporate governance stemming from consumer pressure; the diffusion of practices by multi-national or partner companies or pressure on suppliers to conform to common standards expected by purchasers.

The existence of a common organisational legal framework: health and safety; equal opportunities; registration of companies for financial purposes as examples, has contributed to a degree of homogenisation (Di Maggio and Powell 1983). However not all coercive pressure reflects the needs of organisations to legitimise their operations on a law-based legal governance basis. Corporate governance is increasingly concerned with ethical issues in the conduct of business (Sims 1991). Thus organisations seek external legitimisation on the basis of societal value (Beliveau et al 1994). This suggests that profit maximisation, through rational technological efficiency and process 
controls, is tempered by the needs to satisfy a variety of stakeholder interests, achieved through negotiation.

An additional form of adaptation occurs as a result of mimetic isomorphism. As organisations grow, they frequently imitate the practices of those in a similar task environment, or market sector. In particular, the use of a technique such as benchmarking (Jones 1995), encourages organisations to adopt best practices from those business units perceived to be leaders in a particular environment. A graphic example of mimetic isomorphism can be observed in DiMaggio and Powell's 'The Iron Cage Revisited' (1983) in which the authors examined the 'Japanisation' of organisations in the West. The mimetic isomorphism that has resulted in the adoption of organisational structures replicating those of Japanese industry, is provided as an example of the growth in homogeneity of organisational design which transcend cultures.

Finally, normative isomorphism reflects upon the evolutionary transference of organisational structures and processes as a consequence of the mobility of labour and dominant societal norms and values. Organisations recruit staff trained from external institutions and often experienced in the practices of other companies, and so acquire their familiarity with management knowledge and practices. The diffusion of ideas and behavioural patterns through organisational learning follows.

Di Maggio and Powell (1983) apparently suggested that those organisations which became isomorphic with the dominant institutional environment were likely to be in a more sustainable position than those which had not. Others, for example Jones (1995), argued that the process of isomorphism, mimesis in particular, could have negative implications for companies as a consequence of diminishing innovation. Further, the 'follow-the-leader' approach to strategy, may result in the adoption of practices that are of little relevance to the imitator's needs.

Scott (1986), noted that there is not one but a range of variants of Institutional Theory. Selznick (1996), in a reflective article on the distinction between the 'old' and 'new' of institutional theory, suggested that the former was identified as a means of instilling values in those involved in organisations, resulting in accepted conventions of behaviour. The neo-school of Institutional Theory is more concerned with the activities of organisations in a similar institutional or task environment (Tolbert and Barley 1996). Its focus is largely microorganisational, investigating the adoption of structures and processes based on perceived best practices (DiMaggio and Powell 1983; Finkelstein \& Hambrick 1990; Abrahamson and Hegeman cited in Deephouse 1996, p1029).

Tolbert and Barley (1996), and Tolbert and Zucker (1997), sought to move Institutional Theory beyond a dichotomous position that either change has occurred or has not. The authors suggested that in order to use Institutional 
Theory to understand the nature of the change process, the relationship between action, structuration and institutionalisation needed to be quantified. In this respect, Tolbert and Zucker (1997) provided a staged-model of the institutionalisation process (the model indicated by the aforementioned authors, has been adapted for the purposes of this investigation. See figure 1).

These authors suggested that initially as a consequence of radical environmental shifts, institutions are faced with pressures that undermine the value, or efficiency of existing structural forms. These forces are generally regarded as those relating to, or driving, coercive isomorphism.

Tolbert and Zucker (1997) suggested that the process towards reinstitutionalisation could be represented in a linear, four-stage process: deinstitutionalisation or innovation, habitualisation, objectification and finally sedimentation.

Coercive forces acting on industry and companies, disrupt existing patterns and produce pressures for de-institutionalisation or innovation, during which the companies involved seek a new basis by which to restore their equilibrium with the new environmental conditions (Stachovicz 1992).

Habituation follows, where all the players, or companies in a given 'field' are faced with the same forces of change; decision making is consistent within the group. This part of the process is likely to be typified by a propensity towards resistance to change.

As coercive forces towards re-institutionalisation intensify, organisations look beyond their own field to the wider spectrum of business. Organisations in the stage of objectification show signs of adopting what Abrahamson (Abrahamson 1994 cited in Tolbert and Zucker 1997) described as 'trends': quality circles, employee compassion programmes, teams, management training and development were cited as examples. The question arising from this stage of the process of institutionalisation relates to the adoption of new practices. By defining whether the decision making process has moved beyond the adoption of homogeneous practices distinct to the group, to a more heterogeneous stance, where each individual company is adopting a range of 'fashions' tailored to its own circumstances through theoretical analysis, the rate of progression beyond habitualisation to objectification can be established.

Sedimentation is the final stage in the process at which point full institutionalisation occurs is indicated by the resilience of structures and processes to changes in the environment. Where this occurs, changes will have become internalised, thereby indicating a consensual adoption of a legitimate organisational form. Whilst minor adaptations may occur, in order to break down the sedimented structures, forces must be of significant proportions, such as government legislation. 
Critics of institutional theory (see Oliver 1991) stated that there is an explicit suggestion that organisations related to the institutional constraints through 'passive' acceptance. The authors of this paper recognise this point as being valid, agreeing that there are a number of methods for dealing with environmental and institutional forces. The authors further recognise the validity of the argument that some firms choose to resist institutional pressure, or through innovation create a new environmental dynamic. However, the authors are satisfied that the theoretical basis on which institutional theory is constructed provides sufficient scope for examining both of these areas on the basis of the processual nature of institutionalisation as articulated by Tolbert and Zucker (1997) with their suggestion of interest group resistance, and, the theorised response to environmental pressures at the objectification stage of their model.

\section{Background to the Study}

Organisational change in countries formerly dominated by cultural and structural arrangements dictated and fashioned through the influences of the Communist Parties, provide a unique opportunity for researchers concerned with institutionalisation.

In relation to the subject group being studied in Poland, the implications of: the transition to a market economy; a reduced role for the state; the impact of international competition; and the pressures of compliance with contractual arrangements facilitated through foreign direct investment, have precipitated the de-institutionalisation of large sectors of Eastern European business (Millard 1994; Clark and Soulsby 1995).

Poland has undergone a rapid transformation since the late 1980's. Since 1989, reforming governments have grappled with the need to restructure the Polish economy and to attract foreign direct investment. The goal has been to create a social market system and, as a pre-requisite to this end, strategies privatisation have been pursued.

Central to the interest of this paper, the 1990 'Law of Privatisation' of former State Owned Enterprises (SOE's). This legislation transferred the Polish SOE's into holding corporate groups known as 'National Investment Funds' (NIFs) as a preliminary stage to their conversion to privately owned entities (Frydman et al 1993; Millard 1994; Gross and Steinher 1995).

Much of the initial focus of economic reform related to the macro-economic changes in market regulation. The initial 'Balcerowicz' reforms introduced between 1989 and 1991 and subsequent liberalisation of the market have, over time, achieved impressive rates of annual growth in Polish Gross Domestic Product (7 \% in 1997 (OECD 1998)). However, the consequence of opening domestic markets to external competition has not gone unnoticed. Casson (1993) described the quality and suitability of Polish products as inadequate to 
protect Polish business from the effects of exposure to international trade. Further, the inability of Polish industry to satisfy domestic demand and indeed the necessary purchases of foreign machinery and equipment to renew the industrial infrastructure has led to a significant negative trade balance. Poland's ambition to achieve full member status of the European Union by 2003, has underlined the importance attached to improving Poland's industrial competitiveness.

\section{Business Process Improvement Techniques}

Throughout the industrialised world, organisations have been attempting to improve both their cost-effectiveness and their competitive position through the implementation of 'best practice strategies' (McClenahan 1997). Robson (1997) asserted that the rationale supporting such business process improvement programmes requiring as the author termed it, a 'paradigm shift' in the way in which business operations were conducted, were driven by a number of forces. These stemmed from three distinct triggers namely: technological developments, in particular IT systems; an increased need for customer-focus; increased competition as a result of internationalisation.

Whilst the author did not attribute relative impact of these forces compared to each other, she indicated that the changing nature of business as a consequence of technological sophistication resulted in a more dynamic and turbulent environment. Additional to the increased technological sophistication was that of customer pressure. The restructuring of industry over the past two decades has led to a more customer-focussed approach, was cited as evidence of a shift in the traditional power relationship between supplier and purchaser.

The third driver of organisational transformation cited previously has been as a consequence of the need for competitive survival. Increased competition from so called Asian 'tiger' economy nations. The response of threatened Western companies has been Rowlinson (1997) the mimetic isomorphism, of in particular, Japanese organisational structures, process improvement techniques, and customer focus orientation.

The driving forces resulted in a plethora of prescriptive management scripts and 'solutions': Total Quality management, Lean Production, Business Process Reengineering, Excellence as examples.

The take up of what Abrahamson (1994) referred to as 'trends' in management, have become championed and legitimised by hitherto dominant companies such as General Electric and Xerox. Widely imitated by followers, the very practices alluded to previously, have taken on an almost rule-like status in many sectors of organisational operations. This mimetic adoption has been of concern to institutional theorists such as DiMaggio and Powell (1983); Clarke and Soulsby (1995); Tolbert and Zucker (1997). The question posed is whether the adoption 
of these trends is based upon the rational diffusion of techniques for the purposes technological efficiency (Rowlinson 1997), or, on the basis that they appear legitimised as a result of the successful adoption by champion organisations?

\section{Methodology}

The study undertaken was made up of the manufacturing companies which were members of one of 14 NIFs, created in 1995. The name of the NIF has been withheld due to market sensitivity. Activities of participating business units involved in the group relate to four distinct sectors of industry: automotive (either full unit assembly or parts suppliers $(n=5)$ ), construction $(n=4)$, chemicals $(\mathrm{n}=5)$ and textiles $(\mathrm{n}=6)$.

The empirical investigation was conducted through a questionnaire. The choice of this approach was based on the difficulties involved with translation and retranslation of interview or other qualitative based techniques.

The respondents were individuals responsible for the strategic management of the organisation they represented, holding positions of either Chief Executive Officer, or Company Chair. The data gathered related to their company development activities since becoming members of the NIF. The survey was conducted over a two-month period in 1998.

The questionnaire was designed to generate information required to assess the process of institutionalisation among the subject group. For this purpose the adapted model of Tolbert and Zucker (1997) was employed and thus required evidence that: de-institutionalisation had occurred as a consequence of significant forces at a macro or contractual level and that legitimacy rather than rationality had influenced processual or structural change. The habitualisation stage would be apparent through evidence of mimesis and resistance and that changes adopted were consistent within the group.

In order to proceed beyond objectification it would require to be evident that theorising on company specific change programmes was taking place, that resistance to the change process had been overcome. Finally findings that significant restructuring had been completed would be required to demonstrated in order to satisfy the sedimentation requirements.

Whilst the response rate from within the NIF itself was high at $67 \%$, the small numbers involved relative to the wider industrial population made generalisability difficult. Additionally, the questionnaire method appeared to restrict respondents, many of whom provided lengthy detailed data. It is considered that a multiple methodology as suggested by Creswell (1994) would have been more appropriate. 
The authors are however satisfied that the choice of methodology did provide sufficient responses to make the observations offered in the discussion section of this paper.

\section{Findings}

The questionnaire was designed in sections which yielded information which could be used to satisfy the requirements of the study; namely to assess the extent of institutional progression among the NIF participants. The first section dealt with the major 'triggers' of innovation or de-institutionalisation.

The respondents were asked to indicate the force/forces which were causal to any change in organisational structure/processes. The information was recorded and is presented in table 1 .

Table 1

\begin{tabular}{|l|c|c|c|c|c|}
\hline \multicolumn{1}{|c|}{ Forces } & All & $\begin{array}{c}\text { Auto- } \\
\text { motive }\end{array}$ & $\begin{array}{c}\text { Con- } \\
\text { struction }\end{array}$ & $\begin{array}{c}\text { Chemi- } \\
\text { cal }\end{array}$ & Textile \\
\hline Regulatory & 14 & 3 & 3 & 3 & 5 \\
\hline Economic & 4 & 0 & 0 & 1 & 3 \\
\hline Market instability & 20 & 5 & 4 & 5 & 6 \\
\hline Increased competition & 12 & 3 & 0 & 5 & 4 \\
\hline $\begin{array}{l}\text { Technological } \\
\text { developments }\end{array}$ & 12 & 3 & 4 & 2 & 3 \\
\hline $\begin{array}{l}\text { Socio-cultural } \\
\text { changes }\end{array}$ & 7 & 1 & 3 & 0 & 3 \\
\hline
\end{tabular}

The respondents indicated that a number of external forces operating at a macrolevel had resulted in the need to adopt innovative responses to the new environmental dynamic of changes in the regulatory environment 'privatisation' was reported as the most influential trigger, which had altered significantly market structure. The demise of former trading partners in former COMICON states had increased instability. Additional pressure arose from exposure to international competition associated with increased technological efficiency, as new entrants into the Polish market, increased pressure on the products offered by the group in cost and quality terms. Respondents indicated that some of the coercive changes to orthodox structures/processes came through contractual arrangements with customers. This was particularly evident in automotive sector companies, some of whom were component suppliers to Western owned companies. A further association between the number of process improvement 
programmes and the degree of customer involvement was suggested (see tables 2 and 5).

The first section of the questionnaire also related to the fundamental proposition of the neo-school of Institutionalism, namely, that the process of change was fashioned by the concept of legitimacy over rationality. As such, the respondents were asked from which group or groups did they feel that gaining support for innovation was important. The findings, reported in table 3, indicated that there was a wide constituency of stakeholders associated with the companies surveyed who were deemed as important considerations in the choice of innovative responses to environmental turbulence.

Table 2

\begin{tabular}{|l|c|c|c|c|c|}
\hline & All & $\begin{array}{c}\text { Auto- } \\
\text { motive }\end{array}$ & $\begin{array}{c}\text { Con- } \\
\text { struction }\end{array}$ & $\begin{array}{c}\text { Chemica } \\
1\end{array}$ & Textile \\
\hline $\begin{array}{l}\text { Customer driven } \\
\text { change }\end{array}$ & 14 & 5 & 4 & 3 & 2 \\
\hline $\begin{array}{l}\text { Average number of } \\
\text { change programmes }\end{array}$ & 4.6 & 6.4 & 4.5 & 3.6 & 3.8 \\
\hline
\end{tabular}

Table 3

\begin{tabular}{|l|c|c|c|c|c|}
\hline Group & All & $\begin{array}{c}\text { Auto- } \\
\text { motive }\end{array}$ & $\begin{array}{c}\text { Con- } \\
\text { struction }\end{array}$ & $\begin{array}{c}\text { Chemi- } \\
\text { cals }\end{array}$ & Textiles \\
\hline Government & 1 & 0 & 1 & 0 & 0 \\
\hline Managers & 14 & 4 & 2 & 4 & 4 \\
\hline Employees & 17 & 4 & 4 & 4 & 5 \\
\hline Investors & 9 & 2 & 3 & 1 & 3 \\
\hline Customers & 9 & 3 & 2 & 2 & 2 \\
\hline Business partners & 13 & 2 & 3 & 3 & 5 \\
\hline Community & 8 & 1 & 2 & 3 & 2 \\
\hline
\end{tabular}

The responses drawn from the questionnaire highlighted that consultation with primary stakeholders: managers, employees and potential shareholders was deemed important.

Additional consideration was given to secondary and not insignificant stakeholders which included: business partners, customers and investors. 
Consideration for the local community was more evident in the construction and chemical sectors.

The need for the change programmes adopted to be perceived as legitimate by national government was low by comparison with the other stakeholder groupings.

The initial stages of the research revealed, that macro-environmental dynamics and customer involvement as coercive triggers of change, had resulted in tensions existing between the pre-change structures and the environment. All the respondents had indicated an awareness of the need for innovative responses in order to achieve a new equilibrium. Further, that any initiative to achieve this required the support of a wide range of stakeholders. As such it can be suggested that all the organisations surveyed had passed to the de-institutional stage.

DiMaggio, Powell and other institutionalists argue (Ritti and Silver 1986; Scott 1994; Clarke and Soulsby 1995), that organisations in a turbulent environment through mimesis, will adopt structures and process based on perceived best practice of 'hero' companies within a given field. Such a response to environmental uncertainty should be evident as firms progress to the habitualisation stage of institutionalisation characterised by both common decision making and resistance.

The respondents were therefore asked to provide information on the strategies adopted. In particular, whether changes adopted were benchmarked against leading Polish companies and/or whether changes were benchmarked against leading European companies.

The data obtained indicated that the companies were adopting strategies that they considered to be the Polish norm of the industry in which their company operated. Across all the industrial groupings three main strategic responses were recognised (see table 4).

Table 4

\begin{tabular}{|l|c|c|c|c|}
\hline Strategic response & Automotive & $\begin{array}{c}\text { Con- } \\
\text { struction }\end{array}$ & Chemical & Textile \\
\hline Restructuring & 5 & 4 & 5 & 3 \\
\hline Customer focus & 4 & 3 & 4 & 6 \\
\hline Cost focus & 2 & 4 & 4 & 6 \\
\hline
\end{tabular}

The responses indicated that decision making within the groups was consistent across and within the industrial groups being examined. Organisational restructuring was universal within the automotive and chemical sectors. Typically, de-layering and the move towards a wider functional base, such as the 
introduction of a marketing department. Further, reorientation towards a customer focus was consistently reported across all the industrial sectors. Finally, pursuit of a cost driven strategy was evident, most commonly in reduced employment levels across three sectors: construction, chemical and textiles.

A common approach to decision making across all the industrial sectors had been influenced by the imitation or benchmarking approach to strategy. The emphasis placed on a narrow range of common strategies suggested mimesis within the groups. This could be taken as an indication of progress to the habiltualisation stage. However, this stage of the model presented by Tolbert and Zucker, is typified by interest group resistance also.

The respondents were asked to give information relating to obstacles encountered at the adoption stage of organisational reform. A variety of interest groups were identified as significant obstacles to the programmes at their adoption. Institutional infrastructure arrangements, (Giffin,1997) were further identified as obstacles to the change process demonstrating a number of characteristics, and differed according to the sector. The details are reported in table 5 .

\section{Table 5}

\begin{tabular}{|l|c|c|c|c|c|}
\hline Restraining forces & All & $\begin{array}{c}\text { Auto- } \\
\text { motive }\end{array}$ & $\begin{array}{c}\text { Con- } \\
\text { struction }\end{array}$ & $\begin{array}{c}\text { Chemi- } \\
\text { cal }\end{array}$ & Textile \\
\hline Employees & 9 & 3 & 2 & 1 & 3 \\
\hline Trade Union & 5 & 0 & 2 & 3 & 0 \\
\hline Cultural & 5 & 2 & 1 & 0 & 2 \\
\hline Institutional & 10 & 3 & 2 & 3 & 2 \\
\hline
\end{tabular}

Note: The responses in table 5 reflected a wide range of categories, which for the purposes of the study, were generalised as being cultural and institutional by the authors.

The information drawn from this section of the questionnaire indicated that all the respondents had encountered interest group resistance taking a number of forms.

Employee resistance was evident in the automotive, construction and textiles sectors. The construction and chemical groups further identified trades unions as significant obstacles.

Normative constraints to organisational change manifested themselves through cultural forces; typically conservatism or 'old habits' were more commonly reported in the automotive and textile sectors. 
Institutional infrastructure restraints to change were additionally reported across the organisational fields, differing according to the sector being investigated. The respondents from the automotive sector cited the lack of economic arrangements; currency convertibility and access to foreign investment. Respondents on behalf of the construction and chemical companies reported the existence of legislation empowering trades unions.

The evidence of mimetic behaviour together with evidence of initial interest group resistance, served to indicate that all of those involved in the study had progressed beyond the innovative stage to or beyond habitualisation.

If interest group resistance and mimesis are taken as indicators of habitualisation, then interest group advocacy is suggested in the Tolbert and Zucker model as a means of determining whether organisations had progressed to objectification. In addition, mimesis within an organisational field should be replaced by theorised, organisational specific approaches to organisational change. The subject groups were therefore asked to re-examine the interest group attitudes at present and the programmes of process improvement being adopted.

In all but two companies (one in both the automotive and textile sectors) interest group resistance was largely similar with the positions at the early adoption stage. However, the ranges of theorised responses differed by group (see table 6).

Table 6

\begin{tabular}{|l|c|c|c|c|c|}
\hline Change programmes & All & $\begin{array}{c}\text { Auto- } \\
\text { motive }\end{array}$ & $\begin{array}{c}\text { Con- } \\
\text { struction }\end{array}$ & $\begin{array}{c}\text { Chemi- } \\
\text { cals }\end{array}$ & Textiles \\
\hline TQM & 8 & 4 & 1 & 1 & 2 \\
\hline Quality circles & 5 & 3 & 0 & 0 & 2 \\
\hline Management training & 19 & 5 & 3 & 5 & 6 \\
\hline Employee training & 17 & 5 & 3 & 4 & 5 \\
\hline Team working & 8 & 3 & 1 & 1 & 3 \\
\hline $\begin{array}{l}\text { Performance based } \\
\text { rewards }\end{array}$ & 13 & 3 & 3 & 4 & 3 \\
\hline Employee participation & 8 & 3 & 4 & 1 & 0 \\
\hline Lean production & 3 & 2 & 1 & 0 & 0 \\
\hline Just in time & 3 & 2 & 0 & 1 & 0 \\
\hline Benchmarking & 6 & 2 & 2 & 1 & 2 \\
\hline
\end{tabular}


Change programmes adopted by industrial sector

\begin{tabular}{|l|c|c|c|}
\hline Sector & Total number & Mean & $\begin{array}{c}\text { Standard } \\
\text { deviation }\end{array}$ \\
\hline Automotive sector & 32 & 6.4 & 1.9 \\
\hline Construction & 18 & 4.5 & 1.29 \\
\hline Chemical & 18 & 3.6 & 0.54 \\
\hline Textiles & 23 & 3.8 & 0.40 \\
\hline
\end{tabular}

Performance-based reward systems, management and employee training were the most prominent methods for improving organisational performance, and were largely consistent across the groups. The automotive sector companies in particular reported the experimentation with the widest range of change programmes tailored to their needs. Four of the five companies indicated that a quality (ISO 9000) underpinned all other activities.

The textile and construction sectors had concentrated on a much narrower range of programmes; typically identified as training and bonus systems. Little or no evidence was provided to suggest the widespread adoption of process improvement tools beyond these.

The apparent lack of widespread theorised responses in two of the three sectors could be interpreted as suggesting that they were largely located at the habitualisation stage progressing to objectification. It could further be suggested that the evidence of a wide range of theorised improvement techniques would indicate that the majority of incumbents in the automotive group had progressed towards objectification. However, the question raised by the data relating to the role of the interest group requires further clarification. Of all the companies surveyed, only two companies indicated satisfaction that resistance had diminished; one from each of the automotive and textile sectors. Whether this suggests movement beyond objectification will be dealt with in the discussion part of this paper.

The final section of the questionnaire related to the sedimentation stage of institutionalisation. The respondents were asked in a series of questions about the status of their change programmes. All those sampled indicated that significant alterations continued to be made to existing structures/processes. The researchers concluded from these responses that none of those surveyed had reached this stage.

\section{Discussion}

The aim of this paper was to provide a comparative analysis of the degree of institutionalisation within companies from four industrial sectors, now grouped 
as business units of a NIF. A central objective was to test the applicability of the Tolbert and Zucker model as an instrument for charting this process. The authors are satisfied that the model proved to have a general utility in this respect. The charted progression of the companies under review can be observed in figure 2 , however, there were a number of limitations identified as a consequence of the study.

The first observation related to the apparent uni-directional approach to institutionalisation. The framework indicated a linear process beginning at deinstitutionalisation and ending at sedimentation. In theory the organisations being studied, should over time, progress along a continuum. Little attention in the model however was paid to the possibility that companies could regress. For example where a company had introduced a theorised, organisation specific change programme (i.e. objectification) but this had failed, could it be that the adaptation process would revert back to the mimetic orthodoxy of habitualisation?

An ambiguity associated with certain stages of the framework is the conceptualisation of 'interest group resistance'. Clearly there are many constituencies with varying interests within organisations, therefore, a distinction between the internal and external stakeholders may assist the in defining the origin of that resistance.

Additionally, if the conceptualisation of what is meant by 'interest group' is unclear, then a definitive description of the term 'resistance' is also required: what degree of resistance is significant enough to affect the adaptation process? How does the perception of resistance relate to the motives of the 'interest groups'?

These considerations point to the need for a longitudinal study of the institutionalisation process taking place within organisations requiring close observation of and interaction with organisation members. The opportunity for this was not available to the researchers at that time, although the possibility for a follow-up study at some future date is.

A limitation of the Tolbert and Zucker framework lies with the two dimensional nature of the model. As with many change models (see Lewin cited in Robbins $1997 \mathrm{p}$ 422), the process is perceived as a single entity. The authors suggest that change in organisations is multi-dimensional, progressing at different pace with varying degrees of impact. As such, the whole question of interest group influence is again a source of concern, and also the subjectivity inherent in determining dominant and emergent trends given that the study reflected the observations of senior managers only.

The issue of the speed of the institutionalisation process is relevant to the argument that organisations proceed along a staged continuum. Given the degree of customer driven changes reported, for example within the automotive 
sector might organisations proceed from innovation directly to the theorised objectification stage adopting structures/process replicating those of the dominant party?

The authors are however satisfied, that the study aims and objectives were fulfilled. Additionally, the study has identified further areas of investigation. To this end, the authors have highlighted two key areas for consideration:

If legitimation over rationality is the basis of organisational structuration, and given that the respondents indicated centrality of the employee group as being universally the most significant, what accounts for the high levels of employee resistance indicated?

What is the relationship between customers and change? The findings appeared to suggest a positive correlation between the degree of customer influence and the progression towards institutionalisation.

\section{Conclusion}

That changes to the conventional pre-market structures and processes have taken place is within the organisations studied is evident. The findings indicated that the pace of progression tended to be industrial specific, with some groups more sophisticated than others. The debate on the applicability of the diffusion or institutionalisation of Western managerial orthodoxy (see McLeod \& Baldik 1991; Stachovicz 1992; Kostera \& Wicha 1996; Giffin 1995) has been widely represented from a number of perspectives, the authors hope that this paper has made a contribution to that discussion.

\section{References}

Barley S. and Tolbert P., 1997, Institutionalisation and Structuration: Studying the Links between Action and Institution, Organization Studies, Vol. 18, 1 1997, pp 93 - 118.

Boje D., Gephart R., and Thatchenkery T., 1996, Post-modern Management and Organisational Theory, London, Sage Publications.

Burrel and Morgan, 1979, Sociological Paradigms and Organisational Analysis, London, Sage.

Casson M. Essay in Buckley P., and Ghauri P., 1994, The Economics of Change in East and Central Europe, London, Academic Press.

Chia, 1996, Thirty Years On: From Organisational Structures to the Organisation of Thought, Paper for the BAM Conference, September 1st.

Clark E. and Soulsby A., 1995, Transforming Former State Enterprises in the Czech republic, Organiszation Studies, Vol. 16, N0. 2, pp 215 - 243.

Creswell J., 1994, Research Design: Qualitative and Quantitative Approaches, London, Sage.

Daft R., 1994, Management, Dryden Publishing. 
Damanpour F., 1991, Organizational Innovation: A Meta-analysis of Effects of Determinants and Moderators, Academy of Management Journal, Vol. 34, No. 3, pp 555 -590.

Davis G. and Powell W., 1992, Organization-Environmental Relations, Handbook of Industrial and Organisational Psychology, Vol. 3. Palo Alto, CA: Consulting Psychologists Press pp 317-375.

Deephouse D., 1996, Does Isomorphism Legitimate?, Academy of Management Journal, 1996, Vol. 39, 4, pp 1024 - 1040.

Fox A., 1971, A Sociology of Work in Industry, London, MacMillan.

Frydman R., Rapaczynski A. and Earle J., 1993, The Privatisation Process in Central Europe, London, Central European Press.

DiMaggio P. and Powell W., 1983, The Iron Cage Revisited: Institutional Isomorphism and Collective Rationality in Organizational Fields. American Sociological Review, pp $147-160$.

Gill J. and Johnson P., 1991, Research Methods for Managers, London, Chapman.

Grancelli B., 1995, Organisational Change: Towards an East - West Comparison, Organization Studies, Vol. 16, 1, pp 1 - 26.

Gross D. and Steinherr A., 1995, Winds of Change: Economic Transition in Central and Eastern Europe, New York, Longman.

Hinnings C., Thibault L., Slack T. and Kikulis L., 1996, Values and Organisational Structures, Human Relations, Vol. 49 No. 7, pp 885 - 917.

Giffin P., 1994, Institutional Developments in a Transition Economy, International Journal of Social Economics, 21 (7), 1994, pp 35 - 55.

Jones G., 1995, Organisational Theory, New York, Addison Wesley Publishing Company.

Kostera M. and Wicha M., 1996, The Divided Self of Polish State-owned Enterprises: The Culture of Organizing, Organization Studies, Vol. 17, No.1, pp 83 - 105.

MacLoed D. and Baldick P., 1991, One day Your a Hero, Business Quarterly, Vol. 56, No. 2, pp $27-33$

Meyer J. and Rowan B., 1977, Institutionalized Organisations: Formal Structure as Myth and Ceremony, American Journal of Sociology, Vol. 83, pp 340 - 363.

Millard F., 1994, The Anatomy of the New Poland: Post Communist Politics in its First Phase, Aldershot, Edward Elgar.

Martin G. and Beaumont P., 1997, (in Press)

Mintzberg H., Quinn J. and Ghoshal S., 1995, The Strategy Process: European Edition, London, Prentice Hall.

Oliver C., 1991, Strategic Responses to Institutional Process, Academy of management Review, Vol. 16 pp 425-438.

Razvgorova E. and Wolf-Laudon G., 1991, East-West Joint ventures: The New Business Environment, Oxford, Blackwell.

Ritti R and Silver J., 1986, Early Process of Institutionalization: The Dramaturgy of Exchange in Interorganizational Design, Administrative Science Quarterly

Robbins S., 1997, Management, Prentice Hall. 
Robson W., 1997, Strategic management and information systems: an integrated approach, 2nd edition, Pitman

Rowlinson M., 1997, Organisations and Institutions, London, MacMillan Business.

Schollhammer H, 1994, Strategies and Methodologies in International and Comparative Management Research, Management International Review, Vol. 34, No.4, SPEISS, pp $5-18$.

Selznick P., 1996, Institutionalism 'Old' and 'New', Administrative Science Quarterly, Vol. 41, 2, pp $270-278$.

Scott R, 1994, The Adolescence of Institutional Theory, Administrative Science Quarterly, 32: pp $493-511$.

Sims R., 1991, The Institutionalisation of Organisational Ethics, Journal of Business Ethics, Vol. 10, Netherlands, Kluwer pp 493 - 506.

Stachowicz J., 1992, Management Culture in Large Polish Enterprises in Heavy Industry: Diagnosing the Present State and Identifying the Need for Change, Scand. Journal of Management, Vol. 8. No. 3, pp 247 - 257.

Sutton J., Dobbin F. Meyer J. and Scott R., 1994, The Legalization of the Workplace, American Journal of Sociology, Vol. 99: pp 944-971.

Tolbert P. and Zucker L, 1997, The Institutionalisation of Institutional Theory, Handbook of Organization Studies.

Zucker L., 1977, The Role of Institutionalization in Cultural Persistence, American Sociological Review, Vol. 42: pp 726 - 743.

Electronic Publications

Etchverry S., 1997, Investment Trends for US Business in Poland. 